\title{
Intrakardiális echokardiográfia az elektrofiziológiában
}

\section{Pap Róbert}

\author{
Szegedi Tudományegyetem, II sz. Belgyógyászati Klinika és Kardiológiai Központ, Szeged
}

Levelezési cím: Dr. Pap Róbert, 6725 Szeged, Semmelweis u. 8., E-mail: pap.paprobert@gmail.com

Az intrakardiális echokardiográfia (ICE) manapság széles körben használatos invazív elektrofiziológiai beavatkozások irányítására és monitorozására. A modern ICE-katéterek révén jó minőségű kép alkotható az intrakardiális anatómiáról, az elektrofiziológiai katéterek pozíciójáról, a katéter-endocardium kontaktusról, ezáltal - különösen komplex ritmuszavarok esetén - jelentősen elősegítve a beavatkozás sikerét. Az ICE használata révén bizonyos szövődmények megelőzhetők, illetve korábban felismerhetök, például a perforáció transseptalis punkció közben, pulmonalis véna stenosis, oesophagus-sérülés, thrombusképződés a katétereken és a perikardiális tamponád. Ezáltal az ICE nagyban hozzájárul a beavatkozás biztonságához is.

Kulcsszavak: intrakardiális echokardiográfia, katéterabláció

\section{Intracardiac echocardiography in electrophysiology}

Intracardiac echocardiography (ICE) is widely used for guiding and monitoring invasive electrophysiologic procedures. Modern ICE catheters are capable of providing a good quality image of intracardiac anatomy, electrophysiological catheters and endocardial contact. Thereby they enhance the success of these procedures, especially in cases of complex arrhythmias. Some complications can be prevented, or recognized earlier by the use of ICE, eg. perforation during transseptal catheterization, pulmonary vein stenosis, oesophageal damage, development of thrombi on catheters and pericardial tamponade. This way ICE enhances the safety of the procedure as well.

Keywords: intracardiac echocardiography, catheter ablation

\section{Bevezetés}

Az ICE-katéterek első generációja az 1980-as években jelent meg és egyetlen körbeforgó piezzo elektromos kristályt tartalmazott, amellyel 360 fokos képalkotás lehetséges (1). Az 1990-es években a kisméretű, alacsony frekvenciájú transducerek megjelenésével vált lehetőség a 90 fokos szektorképet létrehozó „phased array" ICE-katéterek bevezetésére. Ezek a nagyobb áthatolóképesség révén lehetővé teszik távolabbi struktúrák leképezését, pl. a jobb pitvarból, illetve kamrából a bal pitvart, illetve a bal kamrát. Ezen túlmenően a „phased array" katéterekkel spektrális- és színes-Doppler-képalkotás is lehetséges (2). A ma használatos katéterek 64 kristályt tartalmaznak, 4,5-10 MHz frekvenciával dolgoznak, 8-10 F átmérőjűek és négy irányban mozgatható véggel rendelkeznek.

\section{Intrakardiális képalkotás}

A katétert leggyakrabban a femoralis vénán és a vena cava inferioron keresztül, a jobb pitvarban helyezzük el. A létrehozott képen kis, aranyszínű marker jelzi a katéter nyelének orientációját (femoralis bevezetés esetén tehát a caudalis irányt), ez általában a szektor bal oldalán helyezkedik el (1. ábra). A katéter jobb pitvarba való bevezetését követően az ultrahangnyaláb általában balra és elöre irányul, ezáltal létrehozva az ún. „home view”-t (1. ábra). Ezen, a jobb pitvar mellett, a cavotricuspidalis isthmus, a tricuspidalis billenytü és a jobb kamra látható. Enyhe, az óramutató járásának megfelelő rotációval az aortagyök és a jobb kamrai kifolyótraktus jelenik meg (2. ábra). Tovább forgatva a katétert a bal pitvar, a mitrális billentyű és a bal pitvari fülcse jönnek a képbe. További, óramutatónak megfelelő rotációval megjelenik a fossa 


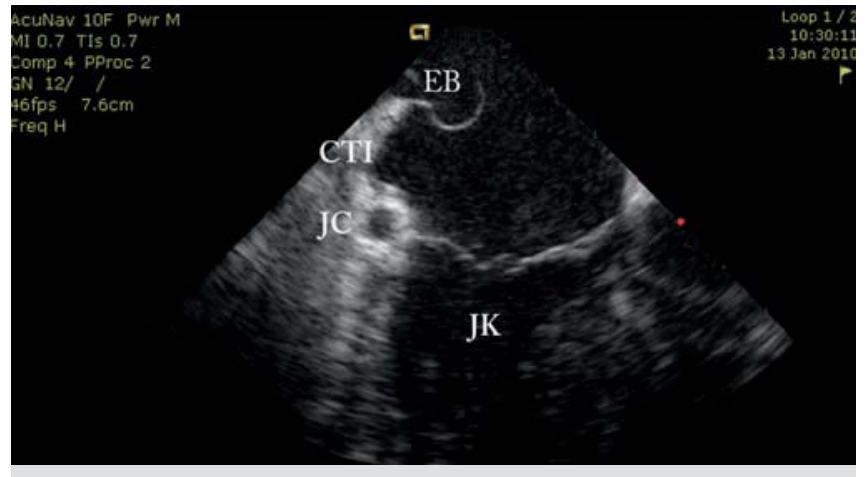

1. ÁBRA. „Home view”. Látható a cavotricuspidalis isthmus (CTI), az Eustach-billentyű (EB), a jobb koronária átmetszete (JC), a tricuspidalis billentyű (Tr) és a jobb kamra (JK)

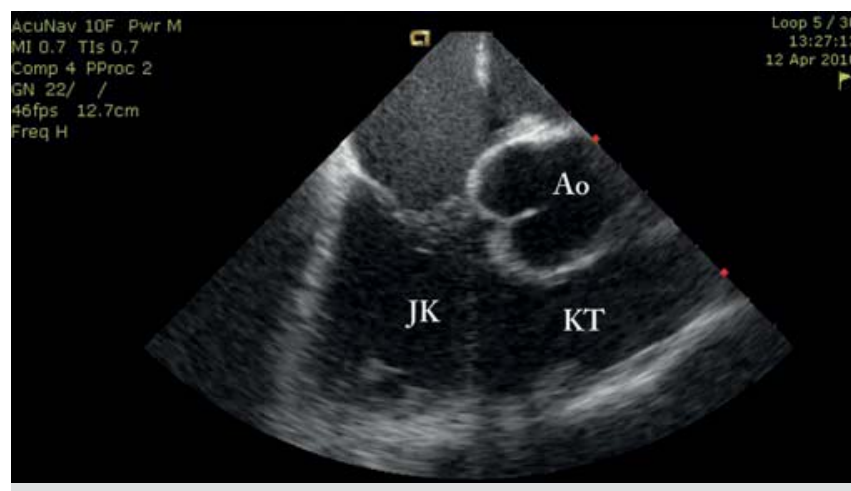

2. ÁBRA. A jobb kamra (JK), jobb kamrai kifolyótraktus (KT) és az aortagyök (Ao) hosszmetszeti képe

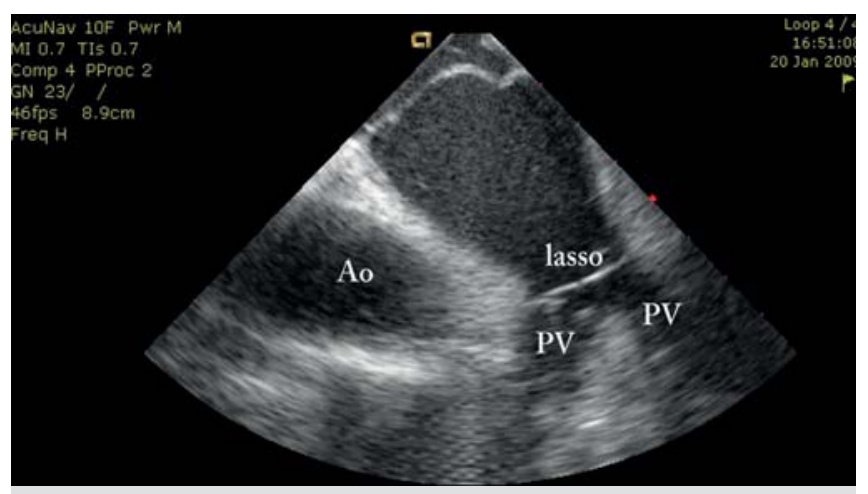

3. ÁBRA. Bal pitvari nézet. A fossa ovalis és a rajta keresztül a bal pulmonalis vénák (PV) rövid közös ostiumába vezetett cirkuláris („lasso") katéter. A képen jobbra a bal felső, balra az alsó PV, mellette a leszálló aorta (Ao)

ovalis a közeli képen és a bal pitvar hátsó része a bal pulmonalis vénákkal (3. ábra). Még további forgatással a bal pitvar hátsó fala, mögötte az oesophagus, majd a jobb pulmonalis vénák láthatók. A bal kamra leképezéséhez a katétert többnyire a jobb kamrába vezetjük, ahonnan a bal kamra hosszanti, illetve további horális rotációval a bal kamrai kifolyótraktus keresztmetszeti képe nyerhető (4. és 5. ábra).

\section{ICE az elektrofiziológiában}

Elektrofiziológiai beavatkozások során az ICE alkalmazásával kontrollálható az eszközök elhelyezése, pozíciója, abláció során a katéter-endocardium kontaktus, a lézió kialakulása és szövődmények megjelenése (thrombus, perikardiális fluidum).

A transseptalis punkció biztonságos kivitelezésében óriási segítséget jelent az ICE használata, különösen az átlagostól eltérő anatómia esetén. A fossa ovalisba pozícionált transseptalis apparátus az ICE-képen a jellegzetes „tenting”-et mutatja (6. ábra). Az ICE segítségével megválasztható a punkció helye (a pulmonalis vénák megközelítése esetén posterior, a mitralis ringet célozva anterior pozícióban).

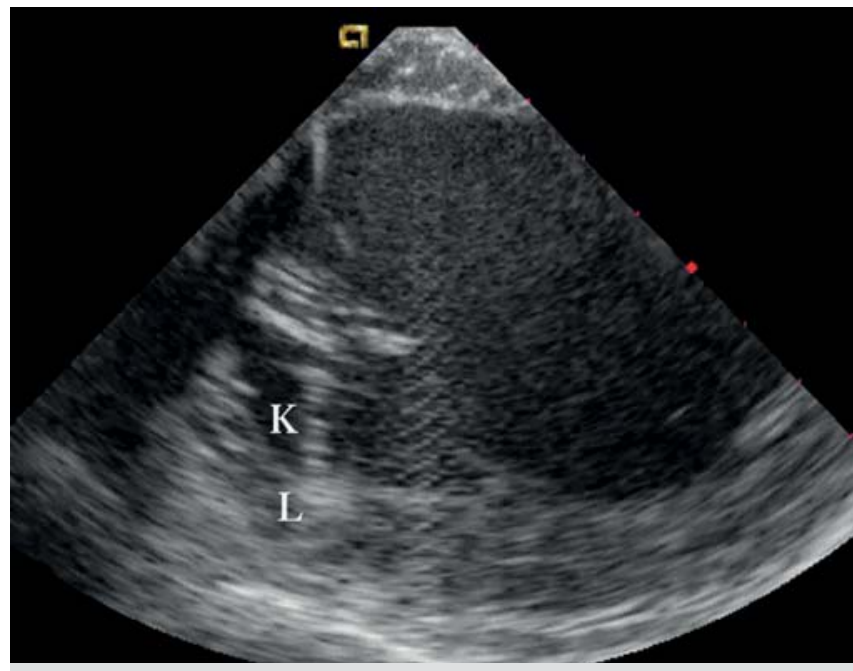

4. ÁBRA. A bal kamra hosszmetszeti képe. Az aortán keresztül a bal kamra inferolateralis falához vezetett ablációs katéter (K) és az abláció hatására a myocardiumban képződött lézió ( $L$ )

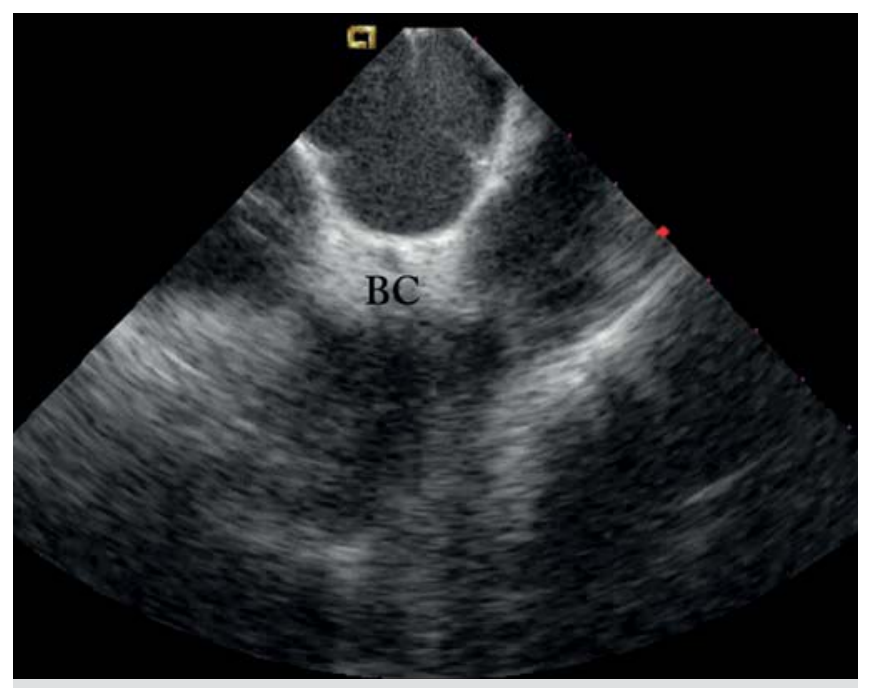

5. ÁBRA. Az aortabillentyű keresztmetszeti képe. Középen a bal koronária $(\mathrm{BC})$ átmetszetével 


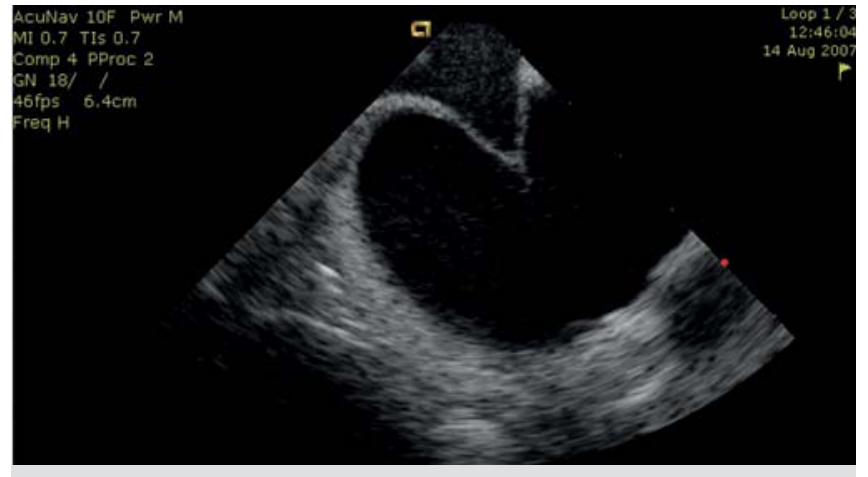

6. ÁBRA. „Tenting” transseptalis punkció közben

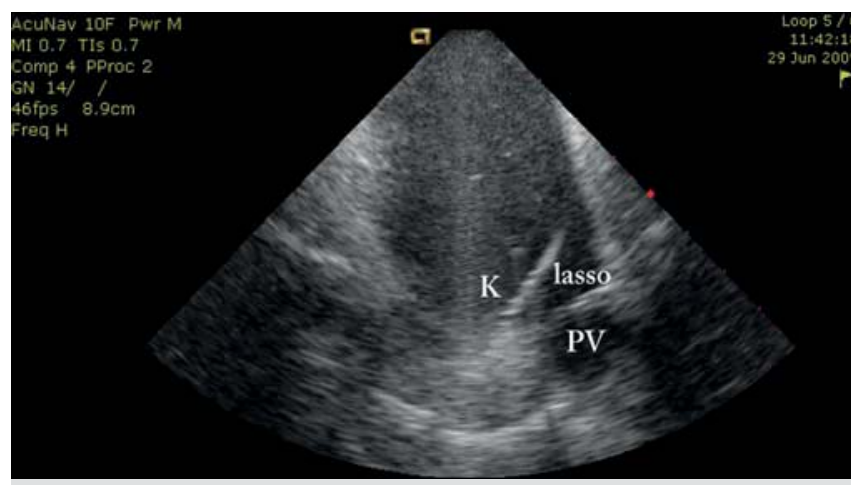

7. ÁBRA. A bal felső pulmonalis véna (PV) izolációja. Látható az ablációs katéter (K) és a PV-ben elhelyezett "lasso" katéter

Elkerülhető az aortagyök, illetve a szabad fal véletlen punkciója (3).

A leggyakrabban pitvarfibrilláció miatt történik bal pitvari beavatkozás, a pulmonalis vénák elektromos izolációját célozva. Az ICE felbecsülhetetlen értékű ezekben az esetekben a pulmonalis vénák rendkívül nagy egyéni variációkat mutató anatómiájának leképezésében, a katéterek pozícionálásában, valamint az extenzív abláció követésében (3. és 7. ábra). A bal pitvar hátsó fala szomszédos az oesophagusszal, amely pulmonalis vénaizoláció kapcsán sérülhet. Az ICE láthatóvá teszi az oesophagust és a közelében történő abláció során az energiaközlés csökkenthető (4).

Pitvari flutter esetén a cavotricuspidalis isthmus a katéterabláció leggyakoribb célpontja. Ez a struktúra hasonlóan a pulmonalis vénákhoz - igen nagy egyedi variabilitást mutat. Leginkább mély recessusok, illetve a prominens Eustach-billentyű gátolhatja az ablációt. Ezeket a jobb pitvarban elhelyezett ICE-katéterrel tökéletesen meg tudjuk jeleníteni és ezáltal az abláció kivitelezése jelentősen könnyebb (1. ábra). Munkacsoportunk korábban randomizált vizsgálatban igazolta az ICE előnyét ebben az applikációban (5). Különösen hasznos az ICE használata kongenitális vitiumokhoz (pl. a Senning-, vagy Mustard-mütét után, Ebstein-anomáliában) társuló pitvari aritmiák esetén a komplex anatómia megjelenítésére.
Az idiopátiás kamrai ritmuszavarok leggyakrabban a bal, illetve a köré csavarodó jobb kamrai kifolyótraktusból, illetve a szomszédos aortatasakokból - a szív legkomplexebb régiójából - erednek. A valós anatómia leképezése az itt végzett ablációk során igen fontos és ennek legjobb eszköze az ICE (6). A transducert a jobb kamrában elhelyezve, majd óramutató irányú rotációt végezve a jobb kamrai kifolyótraktus hosszanti és az aortabillentyű keresztmetszeti képét kapjuk (5. ábra). Megjelenik a jobb kamrai kifolyótraktusba vezetett katéter, a pulmonalis billentyú és -artéria, az aorta bal-, illetve jobb koronáriás tasakjába helyezett katéter és annak távolsága a fő koszorúserektől. Ezáltal a térképezés és abláció hatékonyan és biztonságosabban kivitelezhető, a koronáriáktól biztonságos távolság tartható anélkül, hogy angiográfiára lenne szükség. Az előbbi transducer-pozícióból az óramutató járásával ellentétes rotáció révén a bal kamra hosszmetszeti képét kapjuk (4. ábra). A strukturális szívbetegséghez társuló kamrai tachycardiák nagy része bal kamrai heghez kapcsolódik, amelynek térképezése során igen hasznos a katéter-szövet kontaktus megítélésében, az intracavitális struktúrák (cordae tendineae, papilláris izmok) megjelenítésében, a falmozgászavar, falvékonyodás felismerése révén a heg kiterjedésének megítélésében az $\operatorname{ICE}(7,8)$.

Az ICE használatával bizonyos szövődmények jelentkezése megelőzhető, illetve korai stádiumban felismerhető. Radiofrekvenciás abláció közben monitorozható az ablálandó szövet. Excesszív hőképződés esetén a szövetben apró gázbuborékok jelennek meg, amelyek miatt a szövet fokozottan echogénné válik az ultrahangképen (4. ábra). Amennyiben ilyen, túlfütésre utaló jelek mutatkoznak, az energiaközlés felfüggesztése révén megelőzhető gázerupció, vagy „popping”, amelynek eredménye egyébként kráterképződés, vagy perforáció lehet. Az ICE alkalmazása során felismerhető a szívbe vezetett katétereken, vagy implantált elektródákon képződött thrombus (8. ábra). Adott esetben megelőzhető

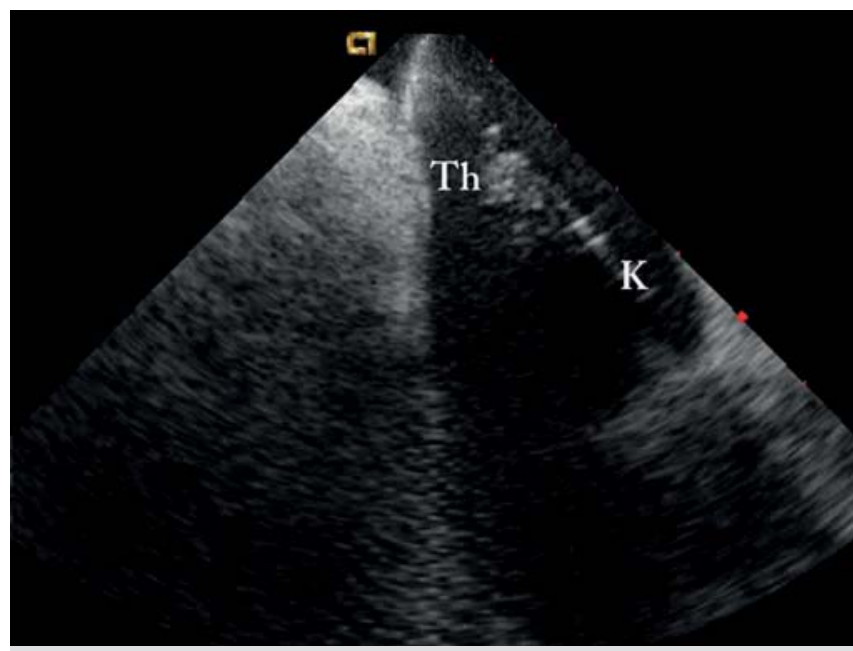

8. ÁBRA. Thrombus (Th) a transseptalisan a bal pitvarba vezetett katéteren (K) 


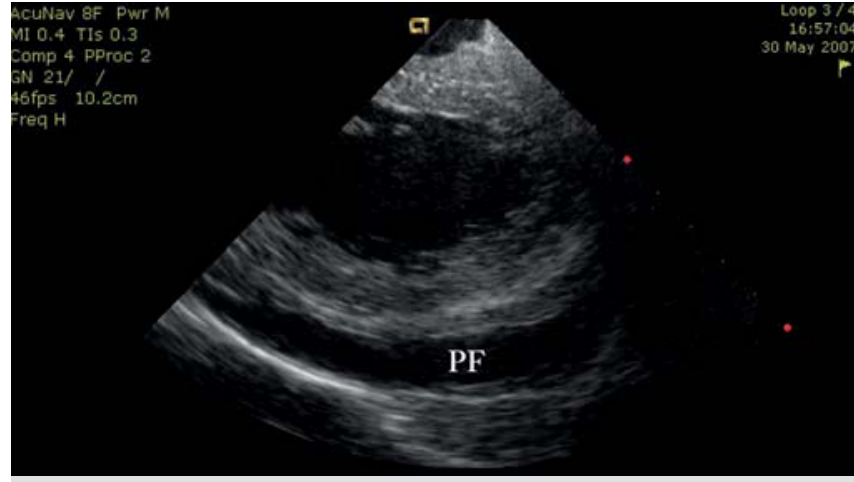

9. ÁBRA. Perikardiális fluidum (PF) a bal kamra körül

ezeknek a szisztémás keringésbe juttatása a beavatkozás során.

A perforációhoz csatlakozó perikardiális folyadékgyülem kialakulását ICE nélkül csak a keringési elégtelenség felléptekor észleljük, míg ICE alkalmazásával korai stádiumban felismerhető, még a tamponád jelentkezése előtt (9. ábra). Ilyenkor, az antikoaguláns terápia felfüggesztésével, esetenként megállítható a folyamat és elkerülhető a sürgős perikardiocentézis, vagy mütét.

Az ICE használata nagyban csökkenti fluoroszkópia és ezáltal az ionizáló sugárzás szükségességét a beavatkozások során, csökkentvén a hosszú távú negatív hatások valószínüségét (9).

\section{Következtetések}

Az ICE használata igazolhatóan javítja a komplex elektrofiziológiai beavatkozások hatékonyságát és biztonságát, egyúttal jelentősen csökkenti a hagyományos fluoroszkópiás tájékozódás szükségességét.
Irodalom

1. Pandian NG1, Kumar R, Katz SE, Tutor A, Schwartz SL, et al. Real-time, intracardiac, two-dimensional echocardiography: enhanced depth of field with a low-frequency (12.5 MHhz) ultrasound catheter. Echocardiography 1991 Jul; 8(4): 407-22. DOI: 10.1111/ j.1540-8175.1991.tb01002.x

2. Bruce CJ, Packer DL, Seward JB. Intracardiac Doppler hemodynamics and flow: new vector, phased-array ultrasound-tipped catheter. Am J Cardiol 1999 May 15; 83(10): 1509-12. A9. DOI: 10.1016/ S0002-9149(99)00136-8

3. Johnson SB, Seward JB, Packer DL. Phased-array intracardiac echocardiography for guiding transseptal catheter placement: utility and learning curve. Pacing Clin Electrophysiol. 2002 Apr; 25(4 Pt 1): 402-7. DOI: 10.1046/j.1460-9592.2002.00402.x

4. Ren JF, Lin D, Marchlinski FE, Callans DJ, Patel V. Esophageal imaging and strategies for avoiding injury during left atrial ablation for atrial fibrillation. Heart Rhythm 2006 Oct; 3(10): 1156-61. DOI: 10.1016/j.hrthm.2006.06.006

5. Bencsik G, Pap R, Makai A, Klausz G, Chadaide S, et al. Randomized trial of intracardiac echocardiography during cavotricuspid isthmus ablation. J Cardiovasc Electrophysiol 2012 Sep; 23(9): 9961000. DOI: 10.1111/j.1540-8167.2012.02331.x

6. Lamberti F, Calo' L, Pandozi C, Castro A, Loricchio ML, et al. Radiofrequency catheter ablation of idiopathic left ventricular outflow tract tachycardia: utility of intracardiac echocardiography. J Cardiovasc Electrophysiol 2001 May; 12(5): 529-35. DOI: 10.1046/j.15408167.2001.00529.x

7. Hussein A, Jimenez A, Ahmad G, Mesubi O, Klein T, et al. Assessment of ventricular tachycardia scar substrate by intracardiac echocardiography. Pacing Clin Electrophysiol 2014 Apr; 37(4): 412-21. doi: 10.1111/pace.12278

8. Pap R, Makai A, Sághy L. Intracardiac echocardiography identifies the substrate of left ventricular papillary muscle ectopy. Europace 2010 Feb; 12(2): 157. doi: 10.1093/europace/eup393.

9. Rigatelli G, Cardaioli P, Roncon L, Giordan M, Bedendo E, et al Impact of intracardiac echocardiography on radiation exposure during adult congenital heart disease catheter-based interventions. Int J Cardiovasc Imaging. 2007 Apr; 23(2): 139-42. DOI: 10.1007/ s10554-006-9125-4

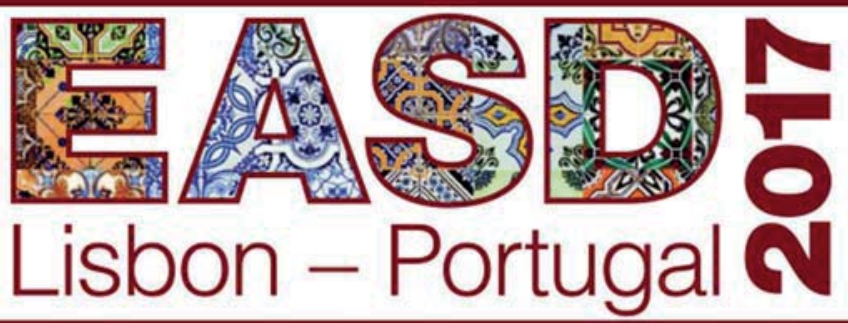

53rd Annual Meeting of the European Association for the Study of Diabetes

11 - 15 September 2017 